\title{
Analysis of Heavy Metals in Blister Pack and Medical Gloves Samples
}

\author{
Monika Martišiūtè ${ }^{1}$, Inga Stasiulaitiene ${ }^{1}$, Gintaras Denafas ${ }^{1}$, Christian Ludwig ${ }^{2,3}$ \\ ${ }^{I}$ Department of Environmental Engineering, Kaunas University of Technology, Lithuania \\ ${ }^{2}$ Swiss Federal Institute of Technology at Lausanne, EPFL-ENAC-IIE, Switzerland \\ ${ }^{3}$ Paul Scherrer Institute, PSI-ENE-LBK, Viligen PSI, Switzerland

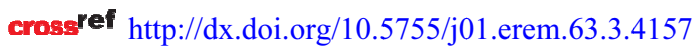

(Received in April, 2013; accepted in September, 2013)

\begin{abstract}
Incineration is a common method to treat medical wastes. Whereas pathogens and environmentally problematic organic compounds are destroyed, toxic heavy metals cannot be ruined. In this study heavy metal concentrations of two types of medical wastes were analyzed. Four different blister pack layers (polyvinyl chloride (PVC), polyvinyl chloride/polyvinylidiene chloride with pigment ( $\mathrm{PVC} / \mathrm{PVdCp}$ ), polyvinyl chloride/polyvinylidiene chloride transparent $(\mathrm{PVC} / \mathrm{PVdCt}$ ) and polyethylene (PE)) and blister pack as a unit, and three types of medical gloves (latex powdered and powder-free medical gloves, nitrile powder-free medical gloves and vinyl powdered and powder-free medical gloves) were digested using high pressure digestion methods. Different acid mixtures were used to digest the samples. Heavy metal concentrations were analyzed by the inductively coupled plasma - optical emission spectrometry (ICP-OES). As, Fe, $\mathrm{Na}, \mathrm{P}, \mathrm{Sn}, \mathrm{Sr}$ and $\mathrm{Zn}$ were detected in blister pack and different blister pack layers. $\mathrm{Ca}, \mathrm{Fe}, \mathrm{K}, \mathrm{Mg}$, $\mathrm{Na}, \mathrm{P}, \mathrm{Sr}$ and $\mathrm{Zn}$ were detected in three different types of medical gloves. No environmentally relevant elemental concentrations were detected except for $\mathrm{Sn}$ and $\mathrm{Zn}$.
\end{abstract}

Keywords: Heavy metals, medical gloves, blister packs, inductively coupled plasma spectroscopy.

\section{Introduction}

Medical wastes are an issue of global concern. Medical wastes are defined as solid or liquid wastes originating from treatment of human beings in hospital or clinic, from clinical diagnosis and pathological testing and from medical research (Patwary et al. 2011). Their danger potential originates from pathogens and infectious components. Moreover, medical waste can consist of radioactive and toxic substances from hospitals, clinical laboratories and medical research institutions. They include sharps (syringes and needles), blood products, human tissues, body parts, pharmaceuticals, cytotoxins, and heavy metals, in addition to the item of general use such as paper, food, plastics, etc (Javied at al. 2008). Medical plastic wastes consist of packing containers, pharmaceutical packages and various medical devices, i.e. gloves, syringes, catheters, etc. Therefore, medical wastes cannot be treated as other municipal wastes.

The USA Environmental Protection Agency (EPA) research data and industry operating experience indicate that incineration has historically been the most widely used treatment technology for the disposal of medical waste (Alagoz et al. 2008). Incineration is a high-temperature dry oxidation process that converts the waste into residual ash and gases. The numerous advantages of incineration (reduction of waste volume, production of energy, saving in landfill cost) have led to its world wide use as a preferred means of treating and disposing of medical solid waste (Alagoz et al. 2007). It is particularly useful in the treatment of pathological 
waste and sharps. It is usually selected to treat wastes that cannot be recycled, reused, or disposed of directly in a landfill site, such as medical wastes (Alagoz et al. 2007, Xie et al. 2009).

Increasing amounts of medicines packaging in blister packs and growing numbers of medical gloves usage lead into investigation of this kind of waste. Most of the blister consists of two - four different types of materials, such as: most common polyvinyl chloride (PVC) and others polyvinyl chloride/polyvinylidiene chloride (PVD/PVdC), polyvinyl chloride/polyethylene/polyvinylidiene chloride (PVC/PE/PVdC), polyvinyl chloride/ polychlorotrifluoroethylene (PVC/ACLAR), polyvinyl chloride/aluminum (PVC/Alu), polyvinyl chloride/cyclic olefin copolymer (PVC/COC), etc (Pilchik 2000, Christopherson R2001). Chosen layers of blister pack quantities and thicknesses can vary to have the best protection properties and excellent barrier against water vapor, oxygen, gas, aroma and taste properties (Jena et al. 2011, Christopherson Ret. al. 2001). Medical gloves can be made of a few different polymers: natural rubber latex, nitrile and vinyl. All medical gloves can be powder-free, or powdered with cornstarch, rice starch or talc $\left(\mathrm{Mg}_{3} \mathrm{Si}_{4} \mathrm{O}_{10}(\mathrm{OH})_{2}\right)$ to lubricate the gloves (STRECH 2011).

The emission of toxic metals from medical waste combustion devices is a potential threat to human health. Metals may exit the waste combustion system either from bottom or filter ashes, or directly via exhaust gases into the environment. Metals cannot be destroyed by incineration, but may be transferred into different compounds. Most of the metals are transferred into the residual ashes. A fraction of the metals originally in the waste may also be found in the exhaust gases emitted from the system (Trouve et al. 1998). Recently, the formation and fate of metal containing nanoparticles originating from waste materials or formation in the incinerator were discussed (Roes et al. 2012, Walser et al. 2012).

The aim of this research is to determine heavy metal concentrations in four types of blister pack layers and blister pack as a unit, and three types of medical gloves using inductively coupled plasma spectroscopy. This is a first step towards the whole assessment of their fate during and after incineration.

\section{Methods}

\section{1. Instrumentation}

In this study a microwave Multiwave 3000 (Perkinelmer, Anton Paar) was used for material digestion. Multiwave 3000 is a versatile and powerful microwave sample digestion system for safe highpressure acid digestions of all types of organic and inorganic samples. For all the above specified materials microwave-assisted acid digestion procedures were performed using a high-pressure digestion system with eight $100 \mathrm{~mL}$ teflon digestion vessels. Different acid mixtures were used for specific material. These procedures were adapted according to the manufacturer's recommendations for various materials.

The digested samples were analyzed with inductively coupled plasma optical emission spectrometry (ICP-OES) (Varian Liberty 110). Analytical ICP-OES operating conditions are listed in

Table 1. ICP-OES operating parameters

\begin{tabular}{|l|l||}
\hline $\begin{array}{l}\text { ICP-OES operating } \\
\text { parameters }\end{array}$ & Value \\
\hline Power & $1.2 \mathrm{~kW}$ \\
Plasma flow & $12 \mathrm{~L} / \mathrm{min}$ \\
Nebulizer flow & $160 \mathrm{kPa}$ \\
Auxiliary flow & $1,5 \mathrm{~L} / \mathrm{min}$ \\
Pump speed & $15 \mathrm{rpm}$ \\
Stabilization time & $25 \mathrm{~s}$ \\
Rinse time & $0 \mathrm{~s}$ \\
Sample delay & $8 \mathrm{~s}$ \\
Element wavelength & $\mathrm{nm}$ \\
& $\mathrm{Sn}(189.926), \mathrm{As}(193.696), \mathrm{Mo}(202.03), \mathrm{Ag}(328.068), \mathrm{Sr}(346.446), \mathrm{Tl}(351.924), \mathrm{Al}$ \\
& $(396.152), \mathrm{Ba}(413.066), \mathrm{Ni}(231.604), \mathrm{Be}(234.861), \mathrm{Co}(237.862), \mathrm{Si}(251.611), \mathrm{Fe}(259.837)$, \\
& $\mathrm{Cr}(267.716), \mathrm{Mn}(279.482), \mathrm{Mg}(279.553), \mathrm{V}(292.402), \mathrm{Na}(588.995), \mathrm{Li}(610.362), \mathrm{B}$ \\
& $(208.893), \mathrm{Ca}(317.933), \mathrm{P}(213.618), \mathrm{Zn}(213.856), \mathrm{Cu}(324.754), \mathrm{Sb}(217.581), \mathrm{Pb}(220.353)$, \\
\hline
\end{tabular}

\section{2. Samples and reagents}

Tested materials used in this study were four blister pack layers (polyethylene (PE), polyvinyl chloride (PVC), polyvinyl chloride/polyvinylidiene chloride with pigment (PVC/PVdCp), polyvinyl chloride/polyvinylidiene chloride transparent (PVC/PVdCt)), blister pack as a unit, latex powderfree (pf) and powdered (p), two types of nitrile pf and vinyl pf and $\mathrm{p}$ medical gloves. Blister pack as a unit and four blister pack layers (Fig. 1.) were collected from Perlen Corverting AG, Switzerland. Medical gloves were obtained from different companies. Nitrile pf, latex pf and vinyl $\mathrm{p}$ and pf glove were obtained from TOP gloves (Malaysia), nitrile pf gloves from Sempercare (USA) and latex p gloves from Baxter (USA) (Fig. 2.). Ultra-high-quality water $(18 \mathrm{M} \Omega \mathrm{cm})$, analytical-grade reagents $\left(\mathrm{HNO}_{3}, \mathrm{HCl}\right.$, $\mathrm{HF}, \mathrm{H}_{2} \mathrm{O}_{2}$, and $\mathrm{HBO}_{3}$ ), control elemental stock standard solutions were used in this study. 


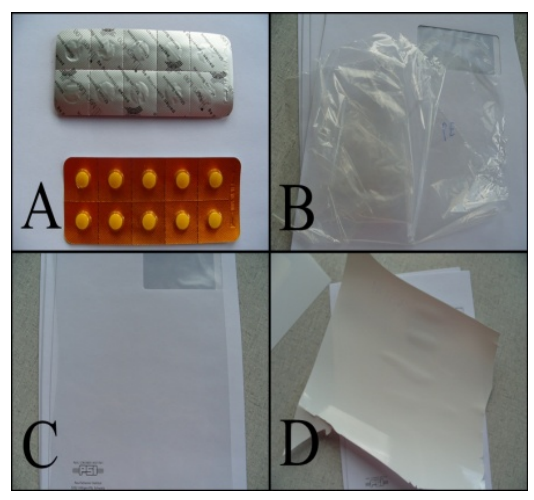

Fig. 1. A - Blister pack; B - PE layer; C - Transparent $P V C ; D-P V C / P V d C$ with pigment;

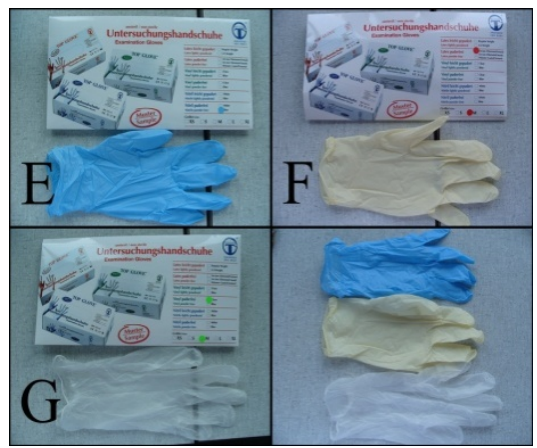

Fig. 2. E-Nitrile pf gloves; F - Latex p, pf gloves; G - Vinyl p, pf gloves;

\subsection{Sample digestion}

Each sample was shredded to small pieces. Approximately $300 \mathrm{mg}$ of cut material was placed into $100 \mathrm{~mL}$ teflon digestion vessels. Two samples were analyzed in parallel.

PVC digestion: Vinyl $\mathrm{p}$ and $\mathrm{pf}$ gloves, blister pack, PVC layer, PVdC/PVCp and PVdC/PVCt layer were filled with $5 \mathrm{~mL}$ of $\mathrm{HNO}_{3}, 1 \mathrm{~mL}$ of $\mathrm{HCl}$ and 1 $\mathrm{mL}$ of $\mathrm{H}_{2} \mathrm{O}_{2}$.

Polyethylene digestion: PE layer material was filled with $7 \mathrm{~mL}$ of $\mathrm{HNO}_{3}$ and $1 \mathrm{~mL}$ of $\mathrm{HF}$.

Rubber digestion - method 1: Latex $\mathrm{p}, \mathrm{pf}$ and nitrile pf gloves were filled with $6 \mathrm{~mL}$ of $\mathrm{HNO}_{3}$ and 2 $\mathrm{mL}$ of $\mathrm{H}_{2} \mathrm{O}_{2}$.

Rubber digestion - method 2: Latex p, pf and nitrile pf gloves were filled with $8 \mathrm{~mL}$ of $\mathrm{HNO}_{3}$ and 1 $\mathrm{mL}$ of HF.

Vessels were tightly closed, placed in a special holder, and heated in the microwave digestor. The operation program is given in

Table 2. After digestion each vessel was carefully opened to release the pressure. The digestate solution was filled with $40 \mathrm{~mL}$ of $\mathrm{HBO}_{3}$ to complex the hydrofluoric acid, diluted with de-ionized water and transferred to a $100 \mathrm{~mL}$ plastic bottle for further analysis by ICP-OES.

After each run, the cleaning process was carried out. Digestion vessels were filled with $6 \mathrm{~mL}$ concentrated $\mathrm{HNO}_{3}$ and cleaning program had been performed. After that all vessels were rinsed with water.

Table 2. Program for microwave Multiwave 3000 digestion of samples

\begin{tabular}{|c|c|c|c|c|c|c|c|c|}
\hline \multirow[b]{2}{*}{ Material } & \multirow[b]{2}{*}{ Method } & \multicolumn{7}{|c|}{ Program } \\
\hline & & $\begin{array}{l}3 \\
\overrightarrow{0} \\
0 \\
0\end{array}$ & $\begin{array}{l}\text { Е } \\
\text { ニ }\end{array}$ & 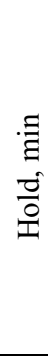 & 胥 & 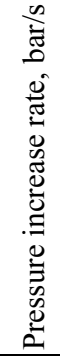 & $\begin{array}{l}0 \\
\cong \\
\cong\end{array}$ & 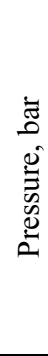 \\
\hline $\begin{array}{l}\mathrm{PVC}, \mathrm{PVC} / \mathrm{PVdC}, \mathrm{PVC} / \mathrm{PVdC} \text { transparent and with } \\
\text { pigment, vinyl powdered and powder-free gloves }\end{array}$ & PVC - I & $\begin{array}{l}800 \\
0\end{array}$ & 15 & $\begin{array}{l}30 \\
20\end{array}$ & $\begin{array}{l}1 \\
3\end{array}$ & 0,2 & 220 & 50 \\
\hline Polyethylene & PE & $\begin{array}{l}700 \\
0\end{array}$ & 5 & $\begin{array}{l}45 \\
20\end{array}$ & $\begin{array}{l}1 \\
3\end{array}$ & 0,2 & 200 & 45 \\
\hline \multirow{2}{*}{$\begin{array}{l}\text { Latex powdered } \\
\text { and latex, nitrile powder-free }\end{array}$} & Rubber - I & $\begin{array}{l}600 \\
0 \\
\end{array}$ & 20 & $\begin{array}{l}15 \\
20 \\
\end{array}$ & $\begin{array}{l}1 \\
3 \\
\end{array}$ & 0,1 & 200 & 40 \\
\hline & Rubber - II & $\begin{array}{l}600 \\
0\end{array}$ & 15 & $\begin{array}{l}30 \\
20\end{array}$ & $\begin{array}{l}1 \\
2\end{array}$ & 0,2 & 220 & 60 \\
\hline Cleaning & - & $\begin{array}{l}800 \\
0\end{array}$ & 10 & $\begin{array}{c}5 \\
20\end{array}$ & $\begin{array}{l}1 \\
2\end{array}$ & 0,5 & 240 & 60 \\
\hline
\end{tabular}

\section{Results}

Four different blister pack layers and blister pack as a unit were analyzed. Blister pack layers were PVC, PE, PVC/PVdCp and PVC/PVdCt. Analytical results are presented in

As was found only in blister pack - 278.58 $\mathrm{mg} \cdot \mathrm{kg}^{-1}$. It means that this element comes from other material, like glue, but not from in this paper analyzed materials. The highest quantity of $\mathrm{Fe}-1604.44$ $\mathrm{mg} \cdot \mathrm{kg}^{-1}$ was measured in blister pack, while the lower quantity was seen in PE layer. The highest quantity of $\mathrm{Na}-591.93 \mathrm{mg} \cdot \mathrm{kg}^{-1}$ was measured in PVC/PVdCp layer, its lower quantities were seen in PVC, PVC/PVdCt layers and in blister pack. $\mathrm{P}$ was measured in both $\mathrm{PVC} / \mathrm{PVdCp}$ layer and blister pack and it consisted of $124.36 \mathrm{mg} \cdot \mathrm{kg}^{-1}$ and $33.39 \mathrm{mg} \cdot \mathrm{kg}^{-1}$, 
respectively. The highest quantity of $\mathrm{Sn}-2873.05$ $\mathrm{mg} \cdot \mathrm{kg}^{-1}$ was measured in PVC layer, while its lower quantities were seen in PVC/PVdCp, PVC/PVdCt layers and in blister pack. $\mathrm{Sr}$ was found only in PVC layer $-1.58 \mathrm{mg} \cdot \mathrm{kg}^{-1}$. A small content of $\mathrm{Zn}$ was discovered in blister pack and PE.

In this study blister pack is made of some quantities of the above analyzed blister pack layers. The $\mathrm{P}$ result shows that our hypothesis is correct and the blister pack is made of $\mathrm{PVC} / \mathrm{PVdCp}$ layer. The $\mathrm{P}$ is found just in blister pack and PVC/PVdCp layer that shows that PVC/PVdCp layer was used in making an analyzed blister pack. $\mathrm{Zn}$ and Fe were detected in the blister pack and it shows that it is made of PE, too.

It is not allowed to sum up the content from original subfractions, as we have no information about the quantity of these fractions used in the blister production. The concentrations can only be used to interpret possible origins of the elements.

Table 3. Metal quantity in blister pack and in layers $\left(\mathrm{mg} \cdot \mathrm{kg}^{-1}\right)$

\begin{tabular}{|c|c|c|c|c|c|}
\hline Method & PVC-1 & PVC-1, & PVC-1 & PVC-1 & $\mathrm{PE}$ \\
\hline Material & Blister pack & PVC & $\begin{array}{l}\mathrm{PVC} / \mathrm{PVdC} \\
\text { without pigment }\end{array}$ & $\begin{array}{l}\text { PVC/PVdC with } \\
\text { pigment }\end{array}$ & $P E$ \\
\hline As & 278.58 & n.d.* & n.d.* & n.d.* & n.d.* \\
\hline $\mathrm{Fe}$ & 1604.44 & n.d. ${ }^{*}$ & n.d.* & n.d.* & 45.98 \\
\hline $\mathrm{Na}$ & 192.33 & 222.2 & 338.51 & 591.93 & n.d.* \\
\hline $\mathrm{P}$ & 33.39 & n.d.* & n.d.* & 124.36 & n.d. $*$ \\
\hline $\mathrm{Sn}$ & 1668.13 & 2873.05 & 1690.51 & 1559.45 & n.d.* \\
\hline $\mathrm{Sr}$ & n.d.* & 1.58 & n.d.* & n.d.* & n.d.* \\
\hline $\mathrm{Zn}$ & 9.44 & n.d.* & n.d.* & n.d.* & 6.24 \\
\hline
\end{tabular}

*-not detected;

Just few of the measured heavy metals were detected in medical gloves. Analytical results are presented in

The highest quantity of $\mathrm{Ca}-168917.5 \mathrm{mg} \cdot \mathrm{kg}^{-1}$ was measured in latex pf using the rubber- 2 method. A similar quantity was found in latex pf using the rubber-1 method. Lower quantities of $\mathrm{Ca}$ were detected in latex $\mathrm{p}$ and nitrile pf using both rubber methods. The highest quantity of $\mathrm{Fe}-68.80 \mathrm{mg} \cdot \mathrm{kg}^{-1}$ was comparably small and measured in latex pf using the rubber- 2 method. Its similar quantity is seen in latex pf using the rubber-1 method, in TG nitrile pf using both rubber methods and in vinyl pf and $p$ gloves. In latex $\mathrm{p}$ and $\mathrm{SC}$ nitrile $\mathrm{pf}$ no $\mathrm{Fe}$ was found. $\mathrm{K}$ was found only in SC nitrile pf gloves - 206.51 $\mathrm{mg} \cdot \mathrm{kg}^{-1}$. The highest quantity of $\mathrm{Mg}-677.61 \mathrm{mg} \cdot \mathrm{kg}^{-1}$ was measured in latex pf using the rubber-2 method.
Table 4. $\quad$ Metal quantity in medical gloves $\left(\mathrm{mg} \cdot \mathrm{kg}^{-1}\right)$

\begin{tabular}{|l|l|l|l|l||}
\hline Method & $\begin{array}{l}\text { Rubber- } \\
1,\end{array}$ & $\begin{array}{l}\text { Rubber- } \\
1\end{array}$ & $\begin{array}{l}\text { Rubber- } \\
1,\end{array}$ & Rubber-1 \\
\hline & $\begin{array}{l}\text { Latex } \\
\text { powdere } \\
\text { Material }\end{array}$ & $\begin{array}{l}\text { Latex } \\
\text { powder- } \\
\text { free }\end{array}$ & $\begin{array}{l}\text { Nitrile } \\
\text { powder- } \\
\text { free } \\
\text { (SC) }\end{array}$ & $\begin{array}{l}\text { Nitrile } \\
\text { powder- } \\
\text { free (TG) }\end{array}$ \\
\hline $\mathrm{Ca}$ & 7372.71 & 156915.9 & 7258.12 & 50701.48 \\
\hline $\mathrm{Fe}$ & n.d.* & 46.28 & n.d. $^{*}$ & 23.72 \\
\hline $\mathrm{K}$ & n.d.* & n.d.* & n.d.* & n.d.* \\
\hline $\mathrm{Mg}$ & 112.63 & 636.38 & 37.34 & 266.58 \\
\hline $\mathrm{Na}$ & n.d.* & n.d.* & 233.74 & 1305.58 \\
\hline $\mathrm{P}$ & 182.81 & 137.00 & 292.12 & 354.09 \\
\hline $\mathrm{Sr}$ & n.d.* & 20.67 & 6.29 & n.d. \\
\hline $\mathrm{Zn}$ & 1087.44 & 2589.97 & 5225.53 & 5534.50 \\
\hline
\end{tabular}

*not detected;

Table 4. Metal quantity in medical gloves $\left(\mathrm{mg} \cdot \mathrm{kg}^{-1}\right)$ (Table 4 continued)

\begin{tabular}{|c|c|c|c|c|c|c|}
\hline Method & Rubber-2 & Rubber-2 & Rubber-2 & Rubber-2 & $\begin{array}{l}\text { PVC-1 } \\
\end{array}$ & $\overline{\text { PVC-1 }}$ \\
\hline $\begin{array}{l}\text { Materia } \\
1\end{array}$ & $\begin{array}{l}\text { Latex } \\
\text { powdered }\end{array}$ & $\begin{array}{l}\text { Latex } \\
\text { powder-free }\end{array}$ & $\begin{array}{l}\text { Nitrile powder- } \\
\text { free (SC) }\end{array}$ & $\begin{array}{l}\text { Nitrile powder- } \\
\text { free (TG) }\end{array}$ & $\begin{array}{l}\text { Vinyl } \\
\text { powder-free }\end{array}$ & $\begin{array}{l}\text { Vinyl } \\
\text { powdered }\end{array}$ \\
\hline $\mathrm{Ca}$ & 6853.51 & 168917.5 & 7183.84 & 52517.9 & n.d.* & n.d.* \\
\hline $\mathrm{Fe}$ & n.d.* & 68.80 & n.d.* & 37.50 & 29.13 & 20.61 \\
\hline $\mathrm{K}$ & n.d.* & n.d.* & 206.51 & n.d.* & n.d.* & n.d.* \\
\hline $\mathrm{Mg}$ & 127.52 & 677.61 & 36.12 & 273.11 & n.d.* & 64.92 \\
\hline $\mathrm{Na}$ & n.d.* & n.d.* & 240.07 & 1241.88 & 368.02 & 312.60 \\
\hline $\mathrm{P}$ & 115.15 & 148.81 & 233.08 & 376.32 & 36.78 & n.d.* \\
\hline $\mathrm{Sr}$ & n.d.* & 21.93 & n.d.* & 6.59 & n.d.* & n.d.* \\
\hline $\mathrm{Zn}$ & 1002.03 & 2748.08 & 5103.13 & 5584.98 & 109.31 & 52.83 \\
\hline
\end{tabular}

* - not detected;

The similar quantity is obtained with the rubber1 method. Lower quantities of $\mathrm{Mg}$ were detected in all other gloves. The highest quantity of $\mathrm{Na}-1305.58$ $\mathrm{mg} \cdot \mathrm{kg}^{-1}$ was measured in $\mathrm{TG}$ nitrile pf using the rubber-1 method, and its similar quantity was detected in TG nitrile pf obtained with the rubber-2 method. Lower quantities of $\mathrm{Na}$ were detected in $\mathrm{SC}$ nitrile pf using both methods and in both vinyl gloves. The highest quantity of $\mathrm{P}-376.32 \mathrm{mg} \cdot \mathrm{kg}^{-1}$ was measured in TG nitrile pf using the rubber-2 method. A similar result was obtained using the rubber-1 method. Lower quantities of $\mathrm{P}$ were detected in SC nitrile pf using both methods, in both latex gloves using both methods and in vinyl pf gloves. The highest quantity 
of $\mathrm{Sr}-21.93 \mathrm{mg} \cdot \mathrm{kg}^{-1}$ was measured in latex pf using the rubber-2 method, its similar quantity was detected in latex pf using the rubber-1 method. Its lower quantities were detected in SC nitrile pf using the rubber-1method and in TG nitrile pf gloves using the rubber-2 method. The highest quantity of $\mathrm{Zn}-$ $5584.98 \mathrm{mg} \cdot \mathrm{kg}^{-1}$ was measured in TG nitrile pf using the rubber- 2 method, its lower quantity was detected in all other types of glove.

\section{Discussion and conclusions}

Use of Multiwave 3000 was a rapid and efficient way to digest the blister pack and medical gloves samples studied. By means of ICP-OES, different heavy metals (Table 1) were detected in all analyzed materials.

Various quantities of $\mathrm{As}, \mathrm{Fe}, \mathrm{Na}, \mathrm{P}, \mathrm{Sn}$ and $\mathrm{Zn}$ were found in blister pack. Fe $-1604.44 \mathrm{mg} \cdot \mathrm{kg}^{-1}$ and $\mathrm{Sn}-1668.13 \mathrm{mg} \cdot \mathrm{kg}^{-1}$ constituted the biggest quantities. The following quantities of the elements were found in PVC layers: $\mathrm{Na}-222.2 \mathrm{mg} \cdot \mathrm{kg}^{-1}, \mathrm{Sn}-$ $2873.05 \mathrm{mg} \cdot \mathrm{kg}^{-1}$ and a small amount of $\mathrm{Sr}-1.58$ $\mathrm{mg} \cdot \mathrm{kg}^{-1} . \mathrm{Na}-591.93 \mathrm{mg} \cdot \mathrm{kg}^{-1}, \mathrm{P}-124.36 \mathrm{mg} \cdot \mathrm{kg}^{-1}$ and $\mathrm{Sn}-1559.45 \mathrm{mg} \cdot \mathrm{kg}^{-1}$ were found in $\mathrm{PVC} / \mathrm{PVdCp}$ layers. In PVC/PVdCt $\mathrm{Na}-338.51 \mathrm{mg} \cdot \mathrm{kg}^{-1}$ and $\mathrm{Sn}-$ $1690.51 \mathrm{mg} \cdot \mathrm{kg}^{-1}$ were found. In PE Fe $-45.98 \mathrm{mg} \cdot \mathrm{kg}$ ${ }^{1}$ and $\mathrm{Zn}-6.24 \mathrm{mg} \cdot \mathrm{kg}^{-1}$ were found.

Various quantities of $\mathrm{Ca}, \mathrm{Fe}, \mathrm{K}, \mathrm{Mg}, \mathrm{Na}, \mathrm{P}, \mathrm{Sr}$ $\mathrm{Zn}$ were detected in medical gloves. By means of both methods the highest concentrations of $\mathrm{Ca}$ and $\mathrm{Zn}$ were detected in $\mathrm{p}$ and pf latex gloves. In nitrile gloves we can see a similar trend, but higher quantities of $\mathrm{Na}$ and $\mathrm{P}$ were detected there compared to latex gloves. The highest concentration of $\mathrm{Na}$ and $\mathrm{Zn}$ was found in vinyl gloves.

From the obtained data it is seen that heavy metals concentrations in original blister packs are generally low. A high As content should be verified in future studies in order to confirm that such high As concentrations may only exceptionally occur. However, similar high values are confirmed for ashes obtained from incineration of medical wastes (Singh 2007). The Sn concentrations were found one order of magnitude higher than in average municipal solid waste samples (Ludwig 2003, Belevi 2000).

In gloves $\mathrm{Sn}$ was not detected, however, $\mathrm{Zn}$ concentrations were found to be about four times higher than in average municipal solid waste (Belevi 2000, Ludwig 2003) what is comparable with the concentrations found in highly contaminated waste wood (Wellinger 2012). It should be considered that a small inorganic content of gloves results in small amounts of ash residues. Therefore, it is expected that they contain elevated concentrations compared to residues from MSW incineration. This may be of particular concern if such ashes are disposed of in landfills without further treatment. Chlorine from PVC is strongly influencing the volatility of metals in incineration (Ludwig 2003). However, PVC gloves contain much lower $\mathrm{Zn}$ concentrations in contrast to the other gloves tested. Mixing different types of gloves could therefore influence the fate of $\mathrm{Zn}$ in an incinerator and its concentration in ash residues.

In this study only clean materials were investigated and contamination occurring during their use was not considered. In addition to $\mathrm{Zn}$ and $\mathrm{Sn}$, other toxic heavy metals may have to be considered to assess real medical wastes.

\section{Acknowledgements}

We thank Dr. R. Struis (PSI) for valuable scientific discussions and his efforts made to establish contacts with different companies. We thank Mr. A. Schuler (PSI) for having supported Monika Martišiūte in performing analytical measurements. This research project was financially supported by the Swiss National Science Foundation (project IZ73Z0 128178/1). Monika Martišiūte's stay at PSI was financed by the EU Socrates/Erasmus programme.

\section{References}

Belevi, H.; Moench, H. Factors determining the element behavior in municipal solid waste incinerators. 1 . Field studies. Environ. Sci. Technol. 2000, 34, 2501-2506. http://dx.doi.org/10.1021/es991078m

Christopherson R., Debbaut B., Rubin Y. Simulation of pharmaceutical blister pack thermoforming using a nonisothermal integral model. Journal of plastic film \& sheeting, VOL. 17-JULY 2001

Javied S., Tufail M., Khalid S., Heavy metal pollution from medical waste incineration at Islamabad and Rawalpindi, Pakistan, Microchemical Journal 90 (2008) 77 81. http://dx.doi.org/10.1016/j.microc.2008.03.010

Jena R.K., Yue C.Y., Anand L. Improvement of thermal bond strength and surface properties of Cyclic Olefin Copolymer (COC) based microfluidic device using the photo-grafting technique. Sensors and Actuators B 157 (2011) 518- 526

http://dx.doi.org/10.1016/j.snb.2011.05.012

Ludwig, Chr., Hellweg, S., Stucki, S., "Municipal Solid Waste Management - Strategies and Technologies for Sustainable Solutions" Springer, Berlin, Heidelberg, New York (2003) p 534

Na D., Yu-feng Z., Yan W., Thermogravimetric analysis and kinetic study on pyrolysis of representative medical waste composition, Waste Management 28 (2008) $1572-1580$.

http://dx.doi.org/10.1016/j.wasman.2007.05.024

Patwary M. A., O'Hare W. T., Sarker M. H., Assessment of occupational and environmental safety associated with medical waste disposal in developing countries: A qualitative approach, Safety Science 49 (2011) 1200-1207. http://dx.doi.org/10.1016/j.ssci.2011.04.001

Perkinelmer. Multiwave 3000 Equipment [Online: $\begin{array}{llll}\text { accessed 20 } & \text { 2012]: }\end{array}$ 
http://www.perkinelmer.com/Catalog/Category/ID/Consum ables $\% 20$ for $\% 20$ Multiwave $\% 203000$

Pilchik R. 2000. Pharmaceutical Blister Packaging, Part 1. Pharmaceutical Technology.

Roes, L., Patel, M.K., Worrell, E., Ludwig, Chr., Preliminary evaluation of risks related to waste incineration of polymer nanocomposites, Science of the Total Environment, 417-418 (2012) 76-86. http://dx.doi.org/10.1016/j.scitotenv.2011.12.030

Rogger, E., Perlen Corverting AG, Switzerland, personal communication (2012)

Singh, S., Prakash, V., Toxic Environmental Releases from Medical Waste Incineration: A Review, Environ. Monit. Assess. (2007) 132:67-81.

http://dx.doi.org/10.1007/s10661-006-9503-3

STRECH, Aquarterly publication of the Malaysian Rubber Export Promotion Council. Third quarter 2011 KDN:PP15077/05/2011 (029772)

Trouve G., Kauffmann A., Delfosse L., Comparative thermodynamic and experimental study of some heavy metal behaviours during automotive shredder residues incineration, Waste Management 18 (1998) 301 \pm 307. http://dx.doi.org/10.1016/S0956-053X(98)00040-3

Walser, T, Limbach, L.K., Brogioli, R., Erismann, E., Flamigni, L.3, Hattendorf, B., Juchli, M., Krumeich, F., Ludwig, Chr., Prikopsky, K., Rossier, M., Saner, D., Sigg, http://dx.doi.org/10.1016/j.wasman.2012.05.015

A., Hellweg, S., Günther, D., Stark, W.J, Persistence of engineered nanoparticles in a municipal solid-waste incineration plant, Nature Nanotechnology 7 (2012) 520 524. http://dx.doi.org/10.1038/nnano.2012.64

Wellinger, M., Wochele, J., Biollaz, S., Ludwig, Chr., Online elemental analysis of process gases with ICP-OES: A case study on waste wood combustion, Waste $\begin{array}{llll}\text { Management } & 32 & \text { (2012) }\end{array}$ http://dx.doi.org/10.1016/j.wasman.2012.05.015
Xie R., Li W., Li J., Wu B., Yi J. Emissions investigation for a novel medical waste incinerator Journal of Hazardous Materials Volume 166, Issue 1, 15 July 2009, Pages 365-371.

http://dx.doi.org/10.1016/j.jhazmat.2008.11.029

Monika Martišiūtè: master student at the Department of Environmental Engineering, Kaunas University of technology.

Main research area: environmental engineering, medical waste management.

Address: Radvilènų pl. 19, LT-50254, Kaunas, Lithuania

Phone: $\quad+37061610615$

E-mail: martisiute.monika@gmail.com

Dr. Inga Stasiulaitienè: lecturer at the Department of Environmental Engineering, Kaunas University of technology.

Main research area: climate change issues, Carbon dioxide sequestration, environmental economics and law.

Address: Radvilënų pl. 19, LT-50254, Kaunas, Lithuania

Phone.: +370-37-300182

E-mail: inga.stasiulaitienè $@$ ktu.lt

Prof. dr. Gintaras Denafas: Department of Environmental Engineering, Kaunas University of technology.

Main research area: waste management and treatment.

Address: Radvilènų pl. 19, LT-50254, Kaunas, Lithuania

Phone.: +370-37-300183

E-mail: gintaras.denafas@ktu.lt

Prof. dr. Christian Ludwig: Paul Scherrer Institute, Viligen PSI, Switzerland

Main research area: waste management and treatment.

E-mail: christian.ludwig@psi.ch 


\title{
Sunkiụjų metalụ medicininių pirštinių ir vaistų pakuotės méginiuose analizè
}

\author{
Monika Martišiūtè ${ }^{1}$, Inga Stasiulaitiené ${ }^{1}$, Gintaras Denafas ${ }^{1}$, Christian Ludwig ${ }^{2,3}$ \\ ${ }^{1}$ Kauno technologijos universitetas, Inžinerinès ekologijos katedra, Lietuva \\ ${ }^{2}$ Lozanos federalinis technikos institutas, Šveicarija \\ ${ }^{3}$ Paul Scherrer institutas, PSI-ENE-LBK, Villigen PSI, Šveicarija
}

(gauta 2013 m. balandžio mèn., priimta spaudai 2013 m. rugsèjo mèn.)

Terminis apdorojimas yra vienas plačiausiai ir dažniausiai taikomų medicininių atliekų apdorojimo būdų. Taikant ši apdorojimo būdą, stabilizuojamos pavojingos medicininès atliekos, sumažinamas jų kiekis ir svoris. Straipsnyje buvo analizuojamas sunkiųjų metalų kiekis dviejų rūšių medicininėse atliekose: blisterio pakelyje ir keturiuose jo sluoksniuose (polivinilo chloridas (PVC), polietilenas (PE), permatomas polivinilo chloridas, dengtas polivinilideno chloridu (PVC/PVdCt), ir polivinilo chloridas, dengtas polivinilideno chloridu su pigmentu (PVc/PVdCp)), bei trijų rūšių medicininèse pirštinèse (lateksinès medicininès pirštinès su milteliais ir be jų, dviejų rūšių nitrilinès medicininès pirštinès be miltelių ir vinilinès medicininės pirštinès su milteliais ir be jų). Visi išvardyti mėginiai buvo skaidomi naudojant aukšto slėgio skaidytuvą Multiwave 3000 (Perkinelmer, Anton Paar). Kiekvienai medžiagai buvo naudojami skirtingi rūgščių mišiniai, kurie buvo parinkti pagal gamintojo rekomendacijas. Suskaidyti ir ištirpinti mèginiai buvo toliau analizuojami indukuotos plazmos optinès emisijos spektrometru (ICP-OES, Varian Liberty 110). $\mathrm{As}, \mathrm{Fe}, \mathrm{Na}, \mathrm{P}, \mathrm{Sn}, \mathrm{Sr}$ ir Zn kiekiai buvo rasti lizdiniame pakelyje ir jo sluoksniuose, o $\mathrm{Ca}, \mathrm{Fe}, \mathrm{K}$, $\mathrm{Mg}, \mathrm{Na}, \mathrm{P}, \mathrm{Sr}$ ir $\mathrm{Zn}$ - medicininėse pirštinèse. Tik aplinkosauginiu požiūriu reikšmingi elementai $\mathrm{Sn}$ ir $\mathrm{Zn}$ - buvo rasti tirtuose mèginiuose. 